\title{
The role of self-concept and expectations in academic achievement: a preliminary study
}

\author{
L.E. Pettersson, R. Muñoz-Luna \\ University of Málaga, Spain
}

\begin{abstract}
As early career students face new challenges at university, the relationship between second language skills and academic success depends upon self-perception to a greater extent than previously assumed. Up to the moment, most levelling courses have focused on developing students' skills in specific subjects in order to bridge the gap between the knowledge that the high school alumni have and university teachers expect them to possess. Yet, early academic failure remains elevated. For this reason, we have decided to focus our English Degree levelling course on academic strategies, expectations and procedures with the aim to disclose the role of students' self-perception on second language performance in an academic context. We have designed a two-staged method consisting of a survey and a standardized placement test to measure learners' self-perception. The results of both stages are measured by following a mixed method procedure, combining quantitative and qualitative analyses. Results show that there is a close relationship between students' self-concepts, academic expectations, and final outcomes. When the learning of new contents occurs by means of a foreign language, the implications of learners' confidence and their academic awareness are even clearer. Therefore, we conclude that learners' self-concepts, and awareness of their academic expectations should play a key role in initial undergraduate training.
\end{abstract}

Keywords: self-concept; expectation; second language performance; levelling course; higher education; learning experience.

\section{Introduction and context}

First year in Higher Education is always demanding for new students who have to face new challenges regarding schedules, contents, levels, and teachers. In a matter of months, a higher level of maturity and autonomy is required from them as part of their academic success. In many universities, first-year undergraduates are offered an introductory levelling course with the aim of providing an overview of contents and expected learning outcomes. In this regard, we aim to focus on a group of English Studies undergraduates, and to examine the role of academic self-perceptions in learners' second language performance. The notions of self-perception and selfconcept are used interchangeably in this paper and refer to the mental image that study subjects possess of themselves as students (Jurkovic, 2013).

Teachers at the University of Malaga have noted a significant gap between the level of knowledge high school alumni are expected to have and actually possess when commencing their university careers. In addition, the teacher-learner dynamics at university places greater emphasis on students as active learners than earlier whereas teachers assume a moderating role. Consequently, first-year students face unexpected difficulties, which in some cases entails early academic failure. In order to decrease the number of first-year dropouts and enhance learning consistency, different degrees have implanted introductory levelling courses to bridge the gap between high-school and university studies. 


\section{State of the art}

In the present paper, we investigate the relationship between students' previous knowledge, academic self-concepts and expected outcomes. Previous research on student achievement tests and learning strategies indicates that mixed-ability groups present too varied score ranges; therefore, strategy-based teaching is not effective in these cases. On the contrary, focusing on self-perceptions and academic awareness contributes to more efficient learning of a foreign language (Jurkovic, 2013, 210). Other studies in the field have addressed motivational aspects across disciplines (Bong, 2004), as well as language awareness in second language academic achievement (Bolitho, et al., 2003). Peacock (2001), Johns (2008), Nacera (2010) and Yasuda (2011), among others, have traditionally analysed the role of language awareness and academic strategies in the process of foreign language learning. However, they did not trace the intersection among students' self-perceptions, academic expectations and motivations, and final academic results.

Several scholars have demonstrated concern for students' awareness of their learning and consequences on academic success. Madsen, García-Jiménez, Páez-Moguer, Jiménez-Cebrián and Pettersson have proposed self-monitoring tasks that enhance learners' performance efficiently. Although these scholars do not address selfperception, they claim that self-reflective activities foment autonomous learning and stimulate critical thinking (2014, 10-11). Similarly, Smith and Kling highlight that the risk of failure is anchored in low self-esteem: "while self-reflection is an extremely powerful process that can significantly improve self-perception, the low perception of self initially held by many individuals will act to prevent them from engaging in any meaningful way in an exploration and evaluation of their existing knowledge and skills acquired through experience” (Smith and Kling, 2011, 16). In these lines, we find that self-assessment makes learners aware of their learning processes, and subsequently, students' achieve better results. We argue that self-reflective learning testifies to the relevance of self-perception to effective learning.

Whereas previous studies have focused on learners' insight into linguistic skills when learning a foreign language, we have opted for a case study of first-year students starting the degree of English Studies. Our aim is to explore the level of selfperception when entering into university, and the extent to which this perception affects their academic expectations and second language performance. In the present preliminary study, the previous variables are considered since we compare and contrast students' self-perception survey results with their second language results in a standardised language placement test.

\section{Defining theoretical constructs}

\section{Self-perception and academic success}

Self-regulating processes seem to play an important role in obtaining high academic marks. Those regulation procedures shape academic self-concepts which are projected onto academic results. The interrelation between students' perception of themselves as capable learners and their confidence in achieving results denotes "[a] relationship [that] is mutually reinforcing: as our self-perception increases, our willingness to engage in learning increases and as a consequence our level of learning achievement 
increases, which in turn improves our self-perception as a learner, and so the cycle continues” (Smith and Kling, 2011, 256).

Self-concepts are more than objective perceptions of ourselves. They are emotions and reactions towards our own attributes (Bong, et al., 2012, 337). Positive results revert to higher self-perceptions, which at the same time produce better academic results. Such virtuous circle leads us to formulate the following research question: what impact does academic self-perception have on actual English performance in academic contexts? Self-efficacy, or the perception on our cognitive capabilities to do an academic task, shapes our own beliefs in our possibilities to do something. Task value will evidently affect our own perception to do it, becoming a good indicator of academic success. Creativity and analytical skills correspond to formal and logical thinking, what has been recently related to academic success as well (González, et al., 2012). Taking into consideration the importance placed on self-perceptions and beliefs in academic success, we claim that subjectivity and emotions play a key role in achieving study objectives. In fact, according to our preliminary results discussed later in this paper, subjective perceptions of the academic reality will lead towards success or failure in empirical academic tests.

\section{Students' academic expectations and academic success}

Students' academic expectations can be understood as knowledge, motivation and affect regarding an academic challenge (Benevides, et al., 2014, 50). These expectations derive from both academic institutions and the individuals who participate in them (e.g. teachers, students, colleagues). In this regard, self-perception encompasses our individual subjective responses to learning as well as the view we think others have of us. According to recent studies in the field, those students having higher expectations from institutions and institutional resources perform poorer academically. On the contrary, those learners expecting higher from their own academic performance and relying on their personal academic skills achieve better results (Benevides, et al., 2014; Muñoz-Luna, 2013). Hence, students' perception of themselves as learners is a major determinant in academic success.

\section{Methods}

Academic failure in the degree of English Studies is often caused by either students having an insufficient level of English from high school, or learners not having the appropriate development of English language skills during the initial years of their studies. While other levelling courses focus on specific subjects that are central to the degree in question, we have opted for a more global approach. Given the importance of self-perception for academic success, the present research is developed during a levelling course which focuses on academic strategies, expectations and procedures.

Students' awareness of their learning processes enhances their performances as active learners. Yet, to measure self-perception is complicated as this cognition self-image is embedded in individual beliefs and emotions. In order to evaluate the scope of selfperception, we have designed a two-staged method consisting of a placement test and a survey (see Appendix). The questions in the survey were elaborated to disclose students' expectations, motivation, awareness of learning process (survey questions based on González, et al., 2012; Jurkovic, 2013), while the placement test was aimed 
at revealing students' actual English level according to the Common European Framework of References for Languages (hereinafter, CEFR). One important issue to clarify is the variables under analysis in this study. The analysis of these variables will provide insight into undergraduates' self-perception and academic expectations. Our research variables are two, and they aim to respond to the general research question: "what impact does academic self-perception have on actual English performance in academic contexts?”:

- Students' academic expectations. What are the academic expectations of a group of first-year undergraduates in the degree of English studies?

- Students' academic self-perceptions. How do undergraduates perceive themselves regarding their own academic performance?

The participants in the study were a group of fourteen first-year undergraduates who were starting their degree in English Studies. These students enrolled in this levelling course in which two of their future teachers explained academic competences and contents they would be learning during the following four years. During the first day of the course, learners participated in both the survey and the placement test described above; they answered the survey firstly, and then the test. In this manner, their answers were not influenced by what they learned in the course, by new information, group pressure or by their own test performance.

\section{Preliminary results and discussion}

The different questions in the self-perception survey provide data corresponding to the following areas, all of them related to our research variables: personal data, participants' background, course expectations, self-evaluation, degree level expectations, perceptions on Inglés Instrumental/Instrumental English. In order to preserve students' identity, subjects were numbered (001M, 002F..., the letter being the indicator of gender). Regarding participants' gender, there were 5 males and 9 females. They were all aged between 18-20 years with the exception of one student over 25.

As an example of high-scoring participant, we have the case of $007 \mathrm{M}$, who obtained the highest mark in the placement test. In this case, a deeper analysis of the research variables in this student's survey shows that both his academic expectations and his self-concept are very high and positive ("I have always been one of the best students in my class”, 007M). On the contrary, 001F shows a significantly lower level at the language placement test, and her self-concept is remarkably different ("I consider myself inefficient when communicating in English”, 001F); moreover, her academic expectations on the degree in English Studies are poorer ("English Studies was not my first degree option", 001F). At this stage, the results shown in this section are partial and tentative as the study sample is small; further implementations of this study are programmed for the next months.

Some language learning factors are inevitably uncontrollable by students. Although they are imperceptible variables, they influence both speed and quality during the learning process. Group make-up, teaching styles and policies, and teacher-student relationships are all actions occurring in the class but they are not always predictable or manageable by students. Nevertheless, there is something they can change, though 
not effortlessly, which is internal to them, and which directly influences their second language performance: their learning self-concept and their academic expectations. In this regard, we agree with Pajares and Schunk who hold that "students' self-concept and self-efficacy beliefs are each related to and help mediate the impact of other motivation constructs on academic achievement” (2001, 254).

It is widely agreed that academic success in a second language is determined by language features of the activity, by the student's knowledge of the topic, and by a number of skills in the students. Within the last group, learners' self-beliefs and concepts of their second language performance result to be crucial in their actual success. Self-beliefs and self-reliance are as important as social perceptions of others, as it is shown by Gomes and Soares (2013, 782); these authors claim that students with lower academic results pay more attention to social relations and extra-curricular activities.

Awareness of the academic self is related to students' metacognitive knowledge, that is, higher-order cognitive processes and strategies which are transferable from L1 to second language. High-scoring students are more confident and, therefore, they expect more from their academic career. On the contrary, the students who present non-realistic and lower perspectives about their academic phase at university have higher probabilities of failure than those learners who visualise their academic tasks clearer (Gomes and Soares, 2013, 787).

\section{Conclusions}

Students' beginnings in Higher Education bring new academic and professional expectations which are more challenging than the ones they used to have in High School (Gomes \& Soares, 2013, 781). Some new undergraduates feel the pressure of challenge and go through their academic times with more anxiety than relief. Families, academic institutions and governments must work cooperatively in order to provide a more comprehensive educational context for students. Closer attention to internal beliefs, concepts and expectations may redound in favour of academic results and learning. Academic success seems to be related to the ability to conceive more ambitious projects and to design alternative routes to achieve scholarly goals. This is the reason why we advocate for more comprehensive levelling courses in higher education as a way to demonstrate the importance of self-concept and academic awareness in obtaining satisfactory results.

\section{Appendix}

\section{Question 1. Indicate your English level according to the European Framework of Reference for Languages.}

$-\mathrm{A} 1$

$-\mathrm{A} 2$

$-\mathrm{B} 1$

$-\mathrm{B} 2$

$-\mathrm{C} 1$

$-\mathrm{C} 2$

- I'm not familiar with the levels of the European Framework of Reference for Languages. 
Question 2. Regarding your academic language skills level:

-1: I cannot use English effectively in any academic context.

-3: I can use English effectively in a few contexts.

-5: I can use English effectively in some academic contexts.

-7:I can use English effectively in many academic contexts.

-10: I use English correctly and effectively in all academic situations.

Question 3. What expectations do you think your English teachers have from you?

- Teachers expect me to have an A2 level of English

- Teachers expect me to have a B1 level of English

- Teachers expect me to have a C1 level of English

- Teachers expect me to be an autonomous and efficient student, apart from having good language skills

Question 4. What is your level of English in use?

- I consider myself efficient when communicating in English (both writing and speaking)

- I consider myself inefficient when communicating in English

- I am more efficient in English when I try to communicate by writing

-I am more efficient in English when I try to communicate by speaking

Question 5. What expectations do you have for your degree?

- I expect to improve my English level (both written and oral skills)

- I expect to learn about England and English-speaking countries

- I expect to learn how to become a good English teacher

- I expect to learn about English literature and culture

- Others: please, specify

Question 6. Was English Studies your first degree option?

-Yes

-No

-If not: My first option was

$$
\text { English Studies was my__ option }
$$

Question 7. Are you aware of the English language difficulties you experience while studying English?

-Yes

-No

Question 8. What difficulties do you normally experience while studying English?

- Pronunciation difficulties

- Lack of vocabulary

- Comprehension difficulties (Difficulties in understanding sentences)

- Production difficulties (speaking and/or writing)

- I cannot identify my language difficulties

- None of the above. Please, indicate:

Question 9. What are your strengths in English language? (You can choose more than one option)

- I am good at speaking in English

- I am good at writing in English

- I am good at reading in English

- I am good at listening in English 
Question 10. Are you aware of your own learning process?

- I know how much I have learned/studied, and I am aware of what I do not know yet

- My studying is well organised and carefully planned

- I schedule my study time as I go

- I do not know about my study progress

Question 11. While studying, when does your concentration start to fail?

- After less than 30 minutes

- After 30-45 minutes

- After 45-60 minutes

- After 60-90 minutes

- I find it hard to concentrate at all

Question 12. While studying... (You can choose more than one option)

- I am connected to the Internet

- I am connected to social networks

- I set my mobile to silence

- I have the tv on

- I need to be undisturbed

Question 13. How do you see yourself as a student of English?

- I have always been one of the best students in my class

- I have been an average student in my class

- English has always been a difficult subject for me, but I always managed to pass

- I have always had very low marks in English

Question 14: My marks in English were usually

- lower than expected

- as expected

- higher than expected

Question 15: Where did you study English?

- at school only

- I have been tutored or taken extra classes outside school

- I have studied abroad

- I am bilingual

- I have tutored other students / children

Question 16: What was your qualification at the University entry exam?

Global mark:

English:

\section{References}

Benevides, A., et al. (2014). O impacto das expectativas na adaptaçâo acadêmica dos estudantes no Ensino Superior. Psico-USF, Bragança Paulista 19(1), 49-60.

Bolitho, R., Carter, R., Hughes, R., Ivanic, R., Masuhara, H. \& Tomlinson, B. (2003). Ten Questions about Language Awareness. ELT Journal, 57(3), 251-259.

Bong, Mimi. (2004). Academic Motivation in Self-Efficacy, Task Value, Achievement Goal Orientations, and Attributional Beliefs. The Journal of Educational Research, 97(6), 287-98.

Bong, Mimi, Catherine Cho, Hyun Seon Ahn and Hye Jin Kim. (2012). Comparison of Self-Beliefs for Predicting Student Motivation and Achievement. The Journal of Educational Research 105(5), 336-52. 
Gomes, Gil and Adriana Benevides Soares. (2013). Inteligência, habilidades sociais e expectativas acadêmicas no desempenho de estudantes universitários. Psicologia: Reflexao e Crítica 26(4), 780-789.

González, M.L., et al. (2012). Autoconcepto y talento: una relación que favorece el logro académico. Psykhe 21(1), 37-53.

Heiberg-Madsen, Lea and Rocio García-Jiménez, Joaguín Páez-Moguer, Ana Jiménez-Cebrián and Lin Elinor Pettersson (2014). Estrategias docentes para la internacionalización del alumnado universitario. SEECI: Prospectiva en innovación y docencia universitaria Madrid: Universidad Complutense de Madrid, 1-15.

Johns, A. (2008). Genre Awareness for the Novice Academic Student: An Ongoing Quest. Language Teaching, 41(2), 237-252.

Jurkovic, V. (2013). Effect of strategy based instruction on achievement test scores in a mixed language ability group of ESP learners. Ibérica, 25, 195-214.

Muñoz Luna, Rosa. (2013). ¿Cómo escriben los universitarios en inglés? Claves lingüísticas y de pensamiento. Sevilla: Thémata.

Nacera, A. (2010). Languages Learning Strategies and the Vocabulary Size. Procedia Social and Behavioural Sciences, 2(2), 4021-4025.

Pajares, Frank and Dale H Schink. (2001). Self-Beliefs and School Success: SelfEfficacy, Self-Concept, and School Achievement. Self-Perception, 239-265.

Peacock, M. (2001). Language Learning Strategies and EAP Proficiency: Teacher Views, Student Views, and Test Results. In J. Flowerdew \& M. Peacock (Eds.), Research Perspectives on English for Academic Purposes (pp. 268-285). Cambridge: Cambridge University Press.

Smith, Larry and Margaret Kling. (2011). The Impact of Self-Perception on Vocational Learning. Vocational Learning, 14, 243-257.

Yasuda, S. (2011). Genre-Based Tasks in Foreign Language Writing: Developing Writers' Genre-Awareness, Linguistic Knowledge, and Writing Competence. Journal of Second Language Writing, 20(2), 111-133. 